\title{
Nurses' contributions to the promotion of exclusive breastfeeding
}

\author{
Contribuições de enfermeiros na promoção do aleitamento materno exclusivo
}

Tássia Regine de Morais Alves ${ }^{1}$, Jovanka Bittencourt Leite de Carvalho ${ }^{1}$, Thais Rosental Gabriel Lopes ${ }^{1}$, Glauber Weder dos Santos Silva ${ }^{1}$, Gracimary Alves Teixeira ${ }^{1}$

Objective: to identify the contributions of nurses in the promotion of exclusive breastfeeding. Methods: integrative review of the literature, in the databases Scientific Electronic Library Online, Database of Nursing, PubMed Central, Cumulative Index to Nursing and Allied Health Literature and Web of Science. Results: nine selected articles from 2,075 retrieved. Main contributions of categorized nurses: Popular health education and home visits as care technologies in Nursing; Permanent education and the interface in exclusive breastfeeding; and Counseling as a supportive strategy. Conclusion: nurses, as members of multi professional teams, play a relevant role in exclusive breastfeeding, contributing to actions that transcend the biological and technical dimension, contemplating the singularity and the lived context of the woman/nursing woman, with promotion of health education activities during the puerperal pregnancy cycle.

Descriptors: Breast Feeding; Nursing Care; Maternal and Child Health; Nurse's Role.

Objetivo: identificar as contribuições de enfermeiros na promoção do aleitamento materno exclusivo. Métodos: revisão integrativa da literatura, nas bases de dados Scientific Eletronic Library Online, Base de Dados em Enfermagem, PubMed Central, Cumulative Index to Nursing and Allied Health Literature e Web of Science. Resultados: nove artigos selecionados de 2.075 recuperados. Principais contribuições de enfermeiros categorizadas: Educação popular em saúde e visita domiciliar como tecnologias do cuidado em Enfermagem; Educação permanente e a interface no aleitamento materno exclusivo; e $\mathrm{O}$ aconselhamento como estratégia de apoio. Conclusão: enfermeiros, como membros de equipes multiprofissionais, desempenham papel relevante no aleitamento materno exclusivo, contribuindo com ações que transcendem a dimensão biológica e tecnicista, contemplando a singularidade e o contexto vivido da mulher/nutriz, com promoção de atividades de educação em saúde durante o ciclo gravídico puerperal.

Descritores: Aleitamento Materno; Cuidados de Enfermagem; Saúde Materno-Infantil; Papel do Profissional de Enfermagem.

\footnotetext{
${ }^{1}$ Universidade Federal do Rio Grande do Norte. Natal, RN, Brazil. 


\section{Introduction}

Exclusive breastfeeding is an important practice for the health of women and children, with the aim of reducing malnutrition and extreme hunger in the first years of life. In many cases, it is responsible for ensuring child survival, minimizing the incidence of breast and ovarian cancer in women, faster uterine involution in the postpartum period, and strengthening the affective bond between the mother-child dyad ${ }^{(1-2)}$.

Among the efforts made to promote exclusive breastfeeding and reduce infant morbidity and mortality, the National Breastfeeding Incentive Program stands out, with actions aimed at the promotion of breastfeeding through the training of health professionals; to protection, through the establishment of labor laws to support breastfeeding; to the control of marketing and commercialization of artificial milks; supporting the society of breastfeeding women through the construction of educational materials, support groups and individual counseling; and to joint housing in maternity wards by encouraging the initiation of breastfeeding immediately after birth ${ }^{(3)}$.

In addition, it is estimated that exclusive breastfeeding can prevent 823,000 child deaths and 20,000 deaths from breast cancer each year. However, in lowand middle-income countries, only $37.0 \%$ of children under six months of age are exclusively breastfed ${ }^{(4)}$.

Notwithstanding this reality, the promotion, protection and support to the practice of breastfeeding is one of the lines of care defined by the Agenda for Commitments for the Integral Health of the Child and Reduction of Infant Mortality. Thus, the nursing consultation aimed at the child has as its objective the promotion, protection and rehabilitation of health, using growth and development as the guiding axis of attention, considered important indicators of the quality of health care for children. One of the most relevant actions is the protection and encouragement of exclusive breastfeeding ${ }^{(5)}$.

From this perspective, the nurse, as a member that provides direct assistance to maternal and child health at all levels of health care, has a unique role in promoting, protecting and encouraging breastfeeding through prenatal and puerperal, in order to stimulate this practice. Due to the complexity of this phenomenon and to the success of this practice, it is necessary to involve formal and informal support networks, family, as well as health professionals ${ }^{(6)}$.

In view of the above, recognizing the importance of nurses in the practice of exclusive breastfeeding for women and children's health, in particular, the objective was to identify the contributions of nurses in promoting exclusive breastfeeding.

\section{Methods}

Integrative literature review, whose purpose is to synthesize results achieved in studies in an orderly, systematic and comprehensive manner, in order to provide information about a subject or theme ${ }^{(7)}$.

In order to elaborate this integrative review, a methodological approach was used that includes six steps: 1 - selection of the guiding question; 2 - definition of criteria for inclusion and exclusion of studies and search in the literature; 3 - determination of the information to be extracted and categorization of the studies; 4- evaluation of studies included in the integrative review; 5- discussion of results; 6- presentation of the review with synthesis of the knowledge produced $^{(7)}$.

The research question was built from the PICO strategy that consists of the identification: population; intervention (or exposure); comparison; and outcome. These four components are essential for the research question and construction of the question to seek evidence in the literature ${ }^{(8)}$. The infant was attributed to $\mathrm{P}$; to I: influence of nursing care; and to 0 : the scientific evidence in the literature on the incentive to exclusive breastfeeding, the following question emerging: what are the contributions of nurses in promoting exclusive breastfeeding? There was no completion of the " $\mathrm{C}$ ", which represents the comparison, since it was not the objective of the investigation.

The search in the literature occurred between November 2017 and April 2018, from the journal por- 
tal of the Coordination of Improvement of Higher Level Personnel by the Federated Academic Community. Databases were included: Scientific Electronic Library Online (SciELO), Database of Nursing (BDENF), PubMed Central, Cumulative Index to Nursing and Allied Health Literature (CINAHL) and Web of Science. These sources were selected because they have national and international publications of wide impact and diversity of indexing of journals.

In order to reduce the possibility of bias, during the elaboration of the revision protocol, we used the controlled descriptors present in the Descriptors in Health Sciences: "Breastfeeding", "Nursing Care" and "Infant", and the identified synonymies in the vocabulary Medical Subject Headings: "Breast Feeding", "nursing care" and "infant".

To cross-link the terms, the Boolean logical operator AND was used in order to obtain a larger number of possible articles that answered the guiding question: breastfeeding AND nursing care AND breastfeeding; breastfeeding AND nursing care; breastfeeding AND breastfeeding. In the international database, we used Breast Feeding and nursing care and infant; Breast Feeding AND nursing care; Breast Feeding AND infant.

The inclusion criteria were: original articles and systematic review that portrayed the nursing contributions in the promotion of breastfeeding in ti- tle and summary; articles in all languages, published in the last 18 years (January 2000 to July 2017). The choice of this temporal cut was motivated by the creation of the Prenatal and Birth Humanization Program, instituted in 2000, as one of the initiatives to reduce neonatal and maternal mortality and morbidity rates.

To extract the data, a careful evaluation was carried out, with an exploratory reading of the articles, with the completion of the adapted instrument ${ }^{(9)}$, containing the following items: article identification (title, database, periodical, authors and language of publication); data (study design, objective, results obtained and conclusion).

In the identification stage, 2,075 articles were found; in the screening stage, 1,463 were excluded because they did not meet the objective of the investigation. Therefore, 28 articles were recovered for evaluation in full, thus composing the eligibility stage. In the inclusion phase, nine of the 28 pre-selected (eligible) articles were included in the review, since 19 were excluded, of which 13 were non-researched and six were repeated (Figure 1) ${ }^{(10)}$.

The selected articles were analyzed in full in a critical and systematized manner, defined to compose the final sample of this integrative literature review, which were grouped into thematic categories and interpreted based on the literature.
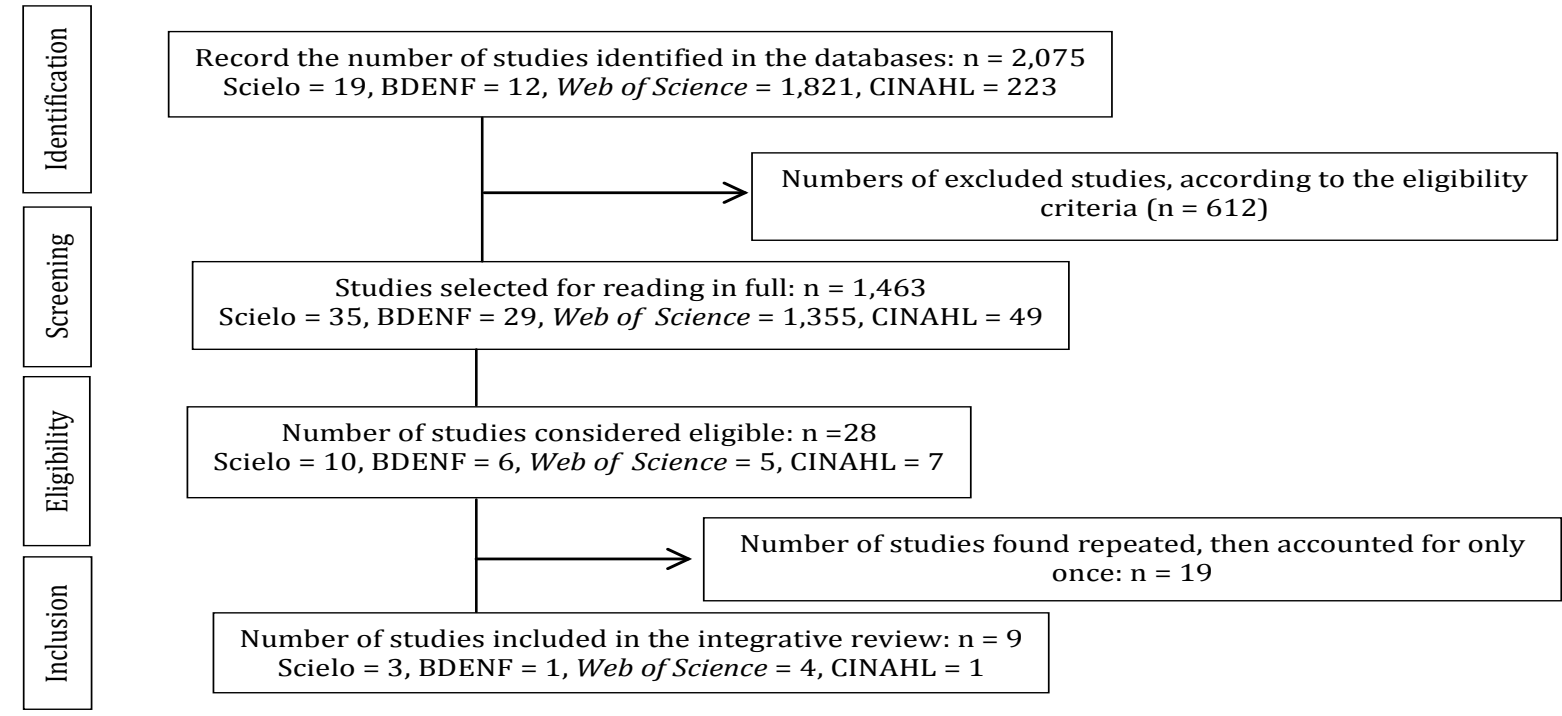

Figure 1 - Flowchart based on PRISMA ${ }^{(10)}$ for review studies 


\section{Results}

In the present integrative review, two (22.2\%) of the articles ${ }^{(11-12)}$ were found in the year 2012. It is emphasized that no production was found that responded to the guiding question of the study, between 2000 and 2007. Regarding the study sites found, Brazil presented the highest index of publications, five
$(55.5 \%)^{(12-15)} ;$ one $(11.1 \%)$ in Portugal ${ }^{(16)} ;$ one (11.1\%) developed in Australia ${ }^{(17)}$; one $(11.1 \%)$ in Pennsylvania ${ }^{(18)}$; one $(11.1 \%)$ in the United States of America $^{(11)}$. Figure 2 summarizes the articles of the final sample, which were presented in chronological order to better explain the evolution of the subject under investigation.

\begin{tabular}{|c|c|c|}
\hline Authors/Years & $\begin{array}{l}\text { Types of study, Levels of Evidence (LE) } \\
\text { and Degrees of Recommendation (DR) }\end{array}$ & Goals \\
\hline Paul IM, et al., 2012 & $\begin{array}{l}\text { Randomized clinical trial } \\
\text { LE }=\text { II } \\
\text { DR = Strong }\end{array}$ & $\begin{array}{l}\text { Compare nursing care with care model using home } \\
\text { nursing visit. }\end{array}$ \\
\hline Queiroz PP, Pontes CM, 2012 & $\begin{array}{l}\text { Descriptive / qualitative approach } \\
\mathrm{LE}=\mathrm{VI} \\
\mathrm{DR}=\text { Weak }\end{array}$ & $\begin{array}{l}\text { Understand the meanings of actions Nursing } \\
\text { education for nursing mothers and family members } \\
\text { attending a breastfeeding clinic. }\end{array}$ \\
\hline Cabral IE, Groleau D, 2009(13) & $\begin{array}{l}\text { Participatory research } \\
L E=V I \\
D R=\text { Weak }\end{array}$ & $\begin{array}{l}\text { To analyze how the knowledge of exclusive } \\
\text { breastfeeding was incorporated in the context of } \\
\text { households. }\end{array}$ \\
\hline Graça LCC, et al., 2011 ${ }^{(14)}$ & $\begin{array}{l}\text { Almost experimental study } \\
\text { LE = III } \\
\text { DR= Moderate }\end{array}$ & $\begin{array}{l}\text { To analyze the contributions of primary care nurses } \\
\text { interventions with primiparous women in the } \\
\text { promotion of breastfeeding. }\end{array}$ \\
\hline Souza RMP, et al., 2015(15) & $\begin{array}{l}\text { Descriptive / qualitative approach } \\
\text { LE }=\text { VI } \\
\text { DR = Weak }\end{array}$ & $\begin{array}{l}\text { To identify the strategies used by nurses in relation to } \\
\text { the clinical management of breastfeeding. }\end{array}$ \\
\hline Teixeira MA, Nitschke RG, 2008(16) & $\begin{array}{l}\text { Descriptive / qualitative approach } \\
\mathrm{LE}=\mathrm{VI} \\
\mathrm{DR}=\text { Weak }\end{array}$ & $\begin{array}{l}\text { Reflect on the implementation of the nursing care } \\
\text { model with three grandmother women and their } \\
\text { families in the process of breastfeeding. }\end{array}$ \\
\hline Cramer RL, et al., $2017^{(17)}$ & $\begin{array}{l}\text { Randomized clinical trial } \\
\text { LE = II } \\
\text { DR = Strong }\end{array}$ & $\begin{array}{l}\text { Describe the profile of women who have sought } \\
\text { community centers for breastfeeding in the } \\
\text { community. }\end{array}$ \\
\hline Ricco-Lizza R, 2016(18) & $\begin{array}{l}\text { Descriptive / qualitative approach } \\
\mathrm{LE}=\mathrm{VI} \\
\mathrm{DR}=\text { Weak }\end{array}$ & $\begin{array}{l}\text { To examine the dietary beliefs and daily feeding } \\
\text { practices of neonatal intensive care unit nurses. }\end{array}$ \\
\hline Alves VH, et al., 2014 $4^{(19)}$ & $\begin{array}{l}\text { Descriptive / qualitative approach } \\
\mathrm{LE}=\mathrm{VI} \\
\mathrm{DR}=\text { Weak }\end{array}$ & $\begin{array}{l}\text { To identify and analyze, from the perspective of } \\
\text { nurses, the process of axiological evaluation of the } \\
\text { promotion, protection and support to breastfeeding. }\end{array}$ \\
\hline
\end{tabular}

Figure 2 - Synthesis of studies included in the interactive review, regarding type, level of evidence and objective 


\section{Discussion}

This review presented as a limitation the lack of articles, based on the adopted parameters, of publications related exclusively to the contributions of nurses to exclusive breastfeeding. However, from the analysis of the content of the publications, it was evidenced that nurses play an assistential role and educator, valuing the insertion of the family nucleus in educational actions and home visits as spaces to promote exclusive breastfeeding. In addition, it uses an important tool for transforming praxis and stimulating it through permanent health education.

The first category of results refers to popular education in health and home visits as nursing care technologies. Regarding the care given to women in the Family Health Strategy, the nurse provides assistance in prenatal care, cervical and breast cancer control, family planning, and the postpartum period. The actions developed in the environment of the health units and at home, through the home visit, enable the continuation of care for women in the pregnancy-puerperal cycle and, at the same time, exclusive breastfeeding ${ }^{(20)}$.

Nurses' interventions during home visits emphasize the quality of life of the child and the protection of breastfeeding. It was evidenced that multiple actions reach positive impact, highlighting the course to the pregnant woman in the prenatal and the puerperal visit. In addition, the involvement of professionals in prenatal care has been an indispensable element to strengthen the bond that extends after birth, fundamental in the defense of the child's health. As a care technology used by nurses, the home visit allows the observation and evaluation not only of the child's condition, but also of the child's life situation, identification of vulnerabilities and realization of preventive guidelines, solicitation of the actions of other professionals and services, as well as promotion of contact between family and team ${ }^{(21)}$.

A meta-analysis study identified that home-based interventions with group counseling, health education, and social mobilization were effective in fos- tering early initiation of breastfeeding in $86.0 \%$; and exclusive breastfeeding, by $20.0 \%{ }^{(22)}$. The studies that compose the review are unanimous in highlighting the differential role that the family designates in the practice of breastfeeding, as co-participants and collaborators of that moment in the life of the puerperal woman and of the newborn ${ }^{(6)}$.

In order to corroborate with the findings of the study, the importance of the home visit conducted by nurses in the puerperium was demonstrated, in which actions related to the counseling, support and care of the woman, the newborn and the family can be developed, in order to provide educational and assistance subsidies, in order to offer emotional support and self-confidence to the woman in the practice of breastfeeding the child ${ }^{(23)}$.

In this context, three studies ${ }^{(12,15,17)}$ emphasized that the insertion of the family can reverse the exclusive breastfeeding indexes and it becomes essential strategies that contemplate the relatives, so that they can see this network of support in all the potentialities and weaknesses.

It is worth mentioning that the participation of the woman/nursing woman, together with the support network in health education activities, such as courses, lectures and groups that address the importance of exclusive breastfeeding, has beneficial effects to the success of this practice, the clarification of doubts, transmission of knowledge and understanding of the social context that translates into support for women ${ }^{(24)}$.

The second category of results refers to permanent education and the interface in exclusive breastfeeding, which is an interactive process to improve the technical and scientific skills associated with the day-to-day conduct of health professionals' procedures and know-how, with a view to transforming the praxis Therefore, one study ${ }^{(16)}$ evaluated nurses' attendance and verified that the professional demonstrated more positive and evidence-based interventions when receiving permanent education about breastfeeding.

One of the causes of discontinuation of exclu- 
sive breastfeeding is disinformation, especially of health professionals. It was verified that the percentage of erroneous information transmission resembles the proportion of mothers who abandon breastfeeding due to the myths related to the theme, which evidences the need to train health professionals to reverse the current scenario of exclusive breastfeeding ${ }^{(25)}$.

Thus, it is necessary to invest in the training of professionals to meet the needs of individuals, aiming to confer the integrality of health care. It is considered the professional education tool capable of generating changes based on the identification of fragilities found in the social context, with a resolution capacity, besides being a determining factor in the construction of competences for work activity as a space of change ${ }^{(26)}$.

The permanent education in the praxis of nurses envisions a path of professional and social transformation, anchored in scientific knowledge and that seeks a nursing care with actions that transcend the biological and technical dimension, assuring integral care. It is understood the importance of these skills for the development of a more qualified professional, providing continuous and updated learning to promote ethical and qualified care, especially in exclusive breastfeeding, and that is a useful tool and base in the counseling process during the nursing consultation.

The third category of results refers to counseling as a support strategy. In this sense, it becomes timely to differentiate the term counseling advice. Counseling is what should be done; counseling is a way of acting, in which the professional listens and understands, offering support for the mother to plan, has autonomy and self-confidence to deal with the difficulties that may arise in the course of breastfee$\operatorname{ding}^{(27)}$.

A study aimed at identifying mothers' perceptions of nurses' practices in promoting breastfeeding revealed that most mothers $(41.5 \%)$ were advised to breastfeed exclusively up to 24 months or more and $31.7 \%$ up to six months. Mothers (86.2\%) reported that most of them were informed about the benefits of exclusive breastfeeding and $64.4 \%$ received information about the legislation regarding labor rights during the exclusive breastfeeding period ${ }^{(28)}$.

Another effective strategy to increase the rates of exclusive breastfeeding in the first month after childbirth was telephone counseling by nurses. Given the importance of this practice, with a view to improving health care for the mother-child dyad and society, counseling should be offered, especially during prenatal and puerperal care, with coherent information, based on scientific evidence ${ }^{(29)}$.

In the present review, an article ${ }^{(15)}$ addressed the counseling technique used by nurses as well as educational activities. It is pointed out that the counseling technique needs to be carried out in a humanized and welcoming way, with active listening of the nurse's wishes and previous experiences of the woman in breastfeeding, so that this practice is successful. It is understood that active listening, warmth, and empathy favor exchanging in communication, providing more detailed and effective counseling for the establishment of practice. The nurse, in counseling, acts as a link between the scientific knowledge and the mother's experience, in order to share the evaluative factors of breastfeeding, besides demystifying beliefs and prejudices ${ }^{(29)}$.

Therefore, it is necessary to rethink and improve the actions of promotion, protection and support to exclusive breastfeeding that must be effective, based on scientific and theoretical knowledge, with strategies that value the particularities of each individual, support of established policies and programs and training of health professionals, who disseminate this practice as a valuable intervention for maternal and child health $^{(30)}$.

\section{Conclusion}

Nurses, as members of multi professional teams, play a relevant role in exclusive breastfeeding, contributing to actions that transcend the biological 
and technical dimension, contemplating the singularity and the lived context of the woman/nursing woman, with promotion of health education activities during the puerperal pregnancy cycle.

\section{Acknowledgement}

To the Coordenação de Aperfeiçoamento de Pessoal de Nível Superior, for fostering the development of this study, with the grant of a Master's degree.

\section{Collaborations}

Alves TRM contributed with design, analysis and interpretation of the data. Lopes TRG, Silva GWS and Teixeira GA collaborated in the writing of the article and relevant critical review of the intellectual content. Carvalho JBL contributed to final approval of the version to be published.

\section{References}

1. Oliveira CS, Locca FA, Carrijo MLR, Garcia RATM. Breastfeeding and complications that contribute to early weaning. Rev Gaúcha Enferm. 2015; 36(esp):16-23. doi: http://dx.doi. org/10.1590/1983-1447.2015.esp.56766

2. Amaral LJX, Sales SS, Carvalho DPSRP, Cruz GKP, Azevedo IC, Ferreira Júnior MA. Factors that influence the interruption of exclusive breastfeeding in nursing mothers. Rev Gaúcha Enferm. 2015; 36(esp):127-34. doi: http://dx.doi. org/10.1590/1983- 1447.2015.esp.56676

3. Ministério da Saúde (BR). Secretaria de Atenção à Saúde. Bases para a discussão da Política Nacional de Promoção, Proteção e Apoio ao Aleitamento Materno. Brasília: Ministério da Saúde; 2017.

4. Victora CG, Barros AJD, França GVA, Bahl R, Rollins $\mathrm{NC}$, Horton $\mathrm{S}$, et al. Amamentação no século 21: epidemiologia, mecanismos, e efeitos ao longo da vida. Epidemiol Serv Saúde [Internet]. 2016 [citado 2018 jul 11]; 1-24. Disponível em: http://scielo.iec.pa.gov.br/pdf/ess/v25n1/ Amamentacao1.pdf
5. Monteschio CAC, Gaíva MAM, Moreira MDS. The nurse faced with early weaning in child nursing consultations. Rev Bras Enferm. 2014; 68(5):86975. doi: 10.1590/0034-7167.2015680515i

6. Lima SP, Santos EKA, Erdmann AL, Souza AIJ. Unveiling the lived experience meaning of being a woman breastfeeding with puerperal complications. Texto Contexto Enferm. 2018; 27(1):e0880016. doi: dx.doi.org/10.1590/010407072018000880016

7. Souza MT, Silva MD, Carvalho R. Integrative review: what is it? How to do it? Einstein (São Paulo) [Internet]. 2010 [cited Jul 11, 2018]; 8(1Pt1):1026. Available from: http://www.scielo.br/pdf/ eins/v8n1/pt_1679-4508-eins-8-1-0102.pdf

8. Galvão TF, Pereira MG. Systematic reviews of the literature: steps for preparation. Epidemiol Serv Saúde [Internet]. 2014 [cited July 11, 2018]; 23(1):183-4. Available from: www.scielo.br/pdf/ ress/v23n1/2237-9622-ress-23-01-00183.pdf

9. Souza V, Zeitoun SS, Barros ALBL. Decreased cardiac output: a systematic review of the defining characteristics. Acta Paul Enferm. 2011;24(1):1149. doi: 10.1590/S0103-21002011000100017

10. Liberati A, Altman DG, Teltzlaff J, Mulrow C, Gøtzsche PC, Loannidis JPA, et al. The PRISMA statement for reporting systematic reviews and meta-analyses of studies that evaluate healthcare interventions: explanation and elaboration. BMJ. 2009; 339:2700. doi: doi.org/10.1136/bmj.b2700

11. Paul IM, Beiler JS, Schaefer EW, Hollenbeak CS, Alleman N, Sturgis SA, et al. A randomized trial of single home nursing visits vs office-based are after Nursery/Maternity Discharge. Arch Pediatr Adolesc Med. 2012; 166(3):263-70. doi: http:// dx.doi.org/1010.1001/archpediatrics.2011

12. Queiroz PP, Pontes CM. Meanings of educative nursing actions centred on breastfeeding from the perspective of breastfeeding mothers and their families. Referência [Internet]. 2012 [cited July 11, 2018]; 3(8):95-103. Available from: http://www. scielo.mec.pt/pdf/ref/vserIIIn8/serIIIn8a10.pdf

13. Cabral IE, Groleau D. Breastfeeding practices after Kangaroo mother method in Rio de Janeiro: the necessity for health education and nursing intervention at home. Esc Anna Nery. 2009; 13(4):763-71. doi: http://dx.doi.org/10.1590/ S1414-81452009000400011 
14. Graça LCC, Figueiredo MCB, Conceição MTCC. Contributions of the nursing intervention in primary healthcare for the promotion of breastfeeding. Rev Latino-am Enfermagem. 2011; 19(2):429-36. doi: dx.doi.org/10.1590/S010411692011000200027

15. Souza RMP, Alves VH, Rodrigues DP, Branco MBLR, Lopes FO, Barbosa MTRS. Nursing strategies in the clinical management of breastfeeding: a descriptive and exploratory study. Online Braz J Nurs [Internet]. 2015 [cited July 11, 2018]; 14(1):51-61. Available from: www.objnursing.uff. br/index.php/nursing/article/view/4612

16. Teixeira MA, Nitschke RG. Modelo de cuidar em enfermagem junto às mulheres-avós e sua família no cotidiano do processo de amamentação. Texto Contexto Enferm. 2008; 17(1):183-91. doi: dx.doi. org/10.1590/S0104-07072008000100021

17. Cramer RL, McLachlan HL, Shafiei T, Amir LH, Cullinare M, Small R, et al. Implementation and evaluation of community-based drop-in centres for breastfeeding support in Victoria, Australia. Int Breastfeeding J. 2017; 12(46):1-14. doi: https:// dx.doi.org/10.1186\%2Fs13006-017-0136-7

18. Ricco-Lizza R. Infant Feeding Beliefs and Day-toDay Feeding practices of NICU nurses. J Pediatr Nurs. 2016; 31(2):e91-e8. doi: https://doi. org/10.1016/j.pedn.2015.10.012

19. Alves VH, Rodrigues DP, Gregório VRP, Branco MBLR, Souza RMP, Alves CMCSH. Reflexions about the value of Breastfeeding as a health practice: a nursing contribution. Texto Contexto Enferm. 2014; 23(1):203-10. doi: http://dx.doi. org/10.1590/S0104-07072014000100024

20. Mazzo MHSN, Brito RS, Santos FAPS. Nurses' activities during postpartum home visit. Rev Enferm UERJ. 2014; 22(5):663-7. doi: http:// dx.doi.org/10.12957/reuerj.2014.15526

21. Andrade RD, Santos JS, Maia MAC, Silva MAI, Veríssimo MLOR, Mello DF. Home visit: care technology used by nurses to advocate for child's health. Texto Contexto Enferm. 2015; 24(4):11308. doi: 10.1590/0104-0707201500000120015
22. Rollins NC, Lutter CK, Bhaandari N, Hajeebhoy N, Horton S, Martines JC, et al. Por que investir e o que será necessário para melhorar as práticas de amamentação? Epidemiol Serv Saúde [Internet]. 2016 [citado 2018 jul 11]; 25-44. Disponível em: www.thelancet.com/series/breastfeeding

23. Prigol AP, Baruffi LM. The role of the nurse in the care of puerperal women. Rev Enferm UFSM. 2017; 7(1):1-8. doi: http://dx.doi. org/10.5902/2179769222286

24. Dias RB, Boery RNSO, Vilela ABA. Conhecimento de enfermeiras e estratégias de incentivo da participação familiarnaamamentação.CiêncSaúde Coletiva. 2016; 21(8):2527-36. doi: http://dx.doi. org/10.1590/1413-81232015218.08942015

25. Almeida JM, Luz SAB, Ued FV. Support of breastfeeding by health professionals: integrative review of the literature. Rev Paul Pediatr. 2015; 33(3):355-62. doi: https://doi.org/10.1016/j. rpped.2014.10.002

26. Salum NC, Prado ML. The permanent education in the development of nursing professionals competences. Texto Contexto Enferm. 2014; 23(2):301-8. doi: dx.doi.org/10.1590/0104070720140021600011

27. Azevedo ARR, Alves VH, Souza RMP, Rodrigues DP, Branco MBLR, Cruz AFN. Clinical management of breastfeeding: knowledge of nurses. Esc Anna Nery. 2015; 19(3):439-45. doi: http://dx.doi. org/10.5935/1414-8145.20150058

28. Castro RJS, Silva BEM, Silva DM. Mothers' perception of nurses' breastfeeding promotion practices. Rev Enferm Ref. 2015; 4(6):65-73. doi: http://dx.doi.org/10.12707/RIV14077

29. Barbosa EMG, Sousa AAS, Vasconcelos MGF, Carvalho REFL, Oriá MO, Rodrigues DP. Educational technologies to encourage (self) care in postpartum women. Rev Bras Enferm. 2016; 69(3):545-53. doi: dx.doi.org/10.1590/00347167.2016690323i

30. Silva MFFS, Pereira LB, Ferreira TN, Souza AM. Breastfeeding self-efficacy and interrelated factors. Rev Rene. 2018; 19:e3175. doi: http:// dx.doi.org/10.15253/2175-6783.2018193175 